\title{
General practitioners' knowledge gaps regarding age related macular degeneration and effectiveness of their e-learning training
}

\author{
Rosa Maria Coco-Martin ${ }^{1}$, Maria Rosa Sanabria ${ }^{1,}{ }^{2}$, Itziar Fernandez ${ }^{1}$, Anna Sala ${ }^{1}$, Carmen \\ Valverde ${ }^{1}$, Raixa Perez ${ }^{3}$ \\ 1. Instituto de Oftalmobiologia Aplicada (IOBA), University of Valladolid, Valladolid, Spain. 2. Complejo Asistencial de \\ Palencia, Palencia, Spain. 3. Direccion General de Planificacion, Calidad, Ordenación y Formacion de la Consejeria de \\ Sanidad de la Junta de Castilla y Leon, Valladolid, Spain
}

Correspondence: Rosa Maria Coco-Martin. Address: Instituto de Oftalmobiologia Aplicada (IOBA), Campus Miguel Delibes, University of Valladolid, Po de Belén no 17, Valladolid, 47011, Spain. E-mail: rosa@ioba.med.uva.es

Received: February 16, 2012

Accepted: April 2, 2012

Online Published: May 5, 2013

DOI : $10.5430 /$ jha.v2n4p37

URL: http://dx.doi.org/10.5430/jha.v2n4p37

\section{Abstract}

Objective: To assess the General Practitioners (GPs) knowledge regarding Age Related Macular Degeneration (ARMD) in order to better design a specific training program, then to evaluate the achievement of their clinical competences in the care of ARMD after taking a specific training program.

Methods: The first part of the study was a postal questionnaire survey sent to all GPs in Castilla \& León. An interactive e-learning program with virtual tutorials was specifically designed for them to cover the identified gaps.

Results: 725 GPs out of 2365 answered the survey, and 44\% of them recognized they did not know the best screening test (Amsler grid). Around 30\% did not know about the bilateralism, prevalence, risk factors, prevention or treatment of ARMD. Younger physicians knew more about ARMD. A specifically designed course was offered to 205 GPs and 164 completed it. We found a higher number of female and younger doctors doing the course compared with the group answering the previous survey. The answer "I do not know" almost disappeared after the course. The probability of suspecting a typical case of ARMD was higher after the course.

Conclusions: The specific interactive online training program focused on covering the identified GPs' gaps led to an effective learning.

\section{Key words}

E-learning technologies, Assessment of clinical competences, Continuing medical education, Age related macular degeneration, General practitioners

\section{I ntroduction}

Continuing medical education (CME) is essential in achieving high quality care of patients and more efficient health services. The American Medical Association defines this CME as all "the educational activities that serve to maintain, develop, or increase the knowledge, skills, and professional performance and relationships a physician uses to provide 
services for patients, the public, or the profession" ${ }^{[1]}$. Since 2007 the Health Government of "Castilla and Leon" (C\&L) established a new system of professional career (PC) that encouraged the professionals to follow CME programs ${ }^{[2]}$. Nevertheless, there is a challenge to demonstrate the effectiveness of these CME programs ${ }^{[3]}$ and the efficient knowledge transfer and didactic clinically integrated teaching approaches ${ }^{[4]}$.

Leaders in medical education foster the identification of high-priority research topics and those will include clinical areas where there is a documented gap between clinical evidence and current practice ${ }^{[5]}$. One of those could be Age Related Macular Degeneration (ARMD). This is a degenerative disorder of the retinal pigment epithelium (RPE) and the neurosensory retina. ARMD is the main cause of legal blindness among the population older than 65 years old in developed countries ${ }^{[6]}$. The more common early symptoms of ARMD are blurring of central vision, reduced visual acuity, metamorphopsia and central scotoma. The Amsler grid is a low-cost and effective screening test for this disease available to GPs ${ }^{[7]}$. Late ARMD includes both the dry and the wet or neovascular forms ${ }^{[8]}$. To date, there is no definitive treatment for the dry form other than modifiable risk factor management ${ }^{[9]}$. But the advent of intravitreal anti vascular endothelial growth factor (anti-VEGF) drugs for the treatment of neovascular ARMD has dramatically changed the outcome of this group of patients ${ }^{[10]}$. Anti-VEGF drugs are not curative but they slow down the progression of the wet form of ARMD reducing the final total area of damaged retina in many cases ${ }^{[11]}$. Those therapeutic options are relatively new and unknown to many GPs. For this reason there are many cases that appear at the Ophthalmologist office at a late stage of the disease and with few possibilities of responding to treatment. ARMD is an increasing health problem in western countries, as this bilateral disease imposes significant functional impairment on patients, leading to increased health resource utilization and a high social cost burden ${ }^{[8]}$. Earlier intervention with effective therapies is expected to reduce disease burden and disability associated with neovascular ARMD ${ }^{[12,13]}$. GPs are frequently the first port of call for patients with ARMD or those considered at risk of developing it and, as such, they have an important role in ensuring that patients receive the best possible care ${ }^{[14]}$.

Educating GPs on its diagnosis and management and covering specifically their identified gaps could reduce population morbidity associated with this disease and its burden of illness. The aims of this study were: first to assess the GPs knowledge regarding ARMD; second to design and perform a specific e-learning training program for them focused on covering the gaps found on that first survey; and third, to assess the effectiveness in the achievement of their clinical competences relating ARMD.

\section{Methods}

This research followed the tenets of the Declaration of Helsinki.

\subsection{Postal questionnaire survey}

Two Ophthalmologists elaborated a first draft of the questionnaire. A focus group, including 2 Ophthalmologist, 1 statistician and 2 GPs, was established to discuss and further develop the definitive questionnaire. Then, an extensive pre-administration piloting of the questionnaire was conducted with a convenient sample of 30 physicians taken from the study population to ensure practicability, validity and interpretation of answers. The questionnaire was conducted twice on the same pilot-sample. Their responses were analyzed and then the questionnaire was readjusted. The final questionnaire consisted of 31 questions related to demographic characteristics, professional experience and knowledge of the disease.

The source population of the survey included all the GPs from the C\&L region of Spain. The basic unit of observation was each physician and the mode of selection was by voluntary participation. All of the participants in the final survey were informed about it and reassured that their anonymity was guaranteed and that their responses would not be used for any other purpose. 
All non-responders received the same questionnaire 3 and 6 weeks later. C\&L health services provide anonymised data about GPs demographics and GP-dependent patients' characteristics. Differences between responders and non-responders were examined, to analyze and correct the effect of the non-responders.

\subsection{Design of the course}

As C\&L is a wide territory, because of that an internet-based course was chosen as the method to deliver the course. The course was made available within the health regional government e-learning platform and offered to all GPs of the region. We provided meaningful interaction between teachers and learners by answering questions in less than 24 hours. Students could also communicate with each other through the course's open forum. Tutors used the forum to promote debates. There were 4 different groups with 50 alumni and 2 assigned tutors for each group.

The course had 7-week duration and it was structured in 8 modules (students had to complete 2 per week). Information presenting the course and pointing out the importance of the disease was sent to the students the first week of the course. Each module had several Internet links that supplemented the content of the course, and 4 multimedia videos were performed as summary of the 2 modules covered each week. After the 8th module, a summary of the course was sent to the participants and alumni had the last 2 weeks to let them finish the obligatory tasks of the course. Alumni had a glossary of terms and acronyms available during the course. Objectives and contents of the course are presented on Table 1.

Table 1. Objectives and contents of the course

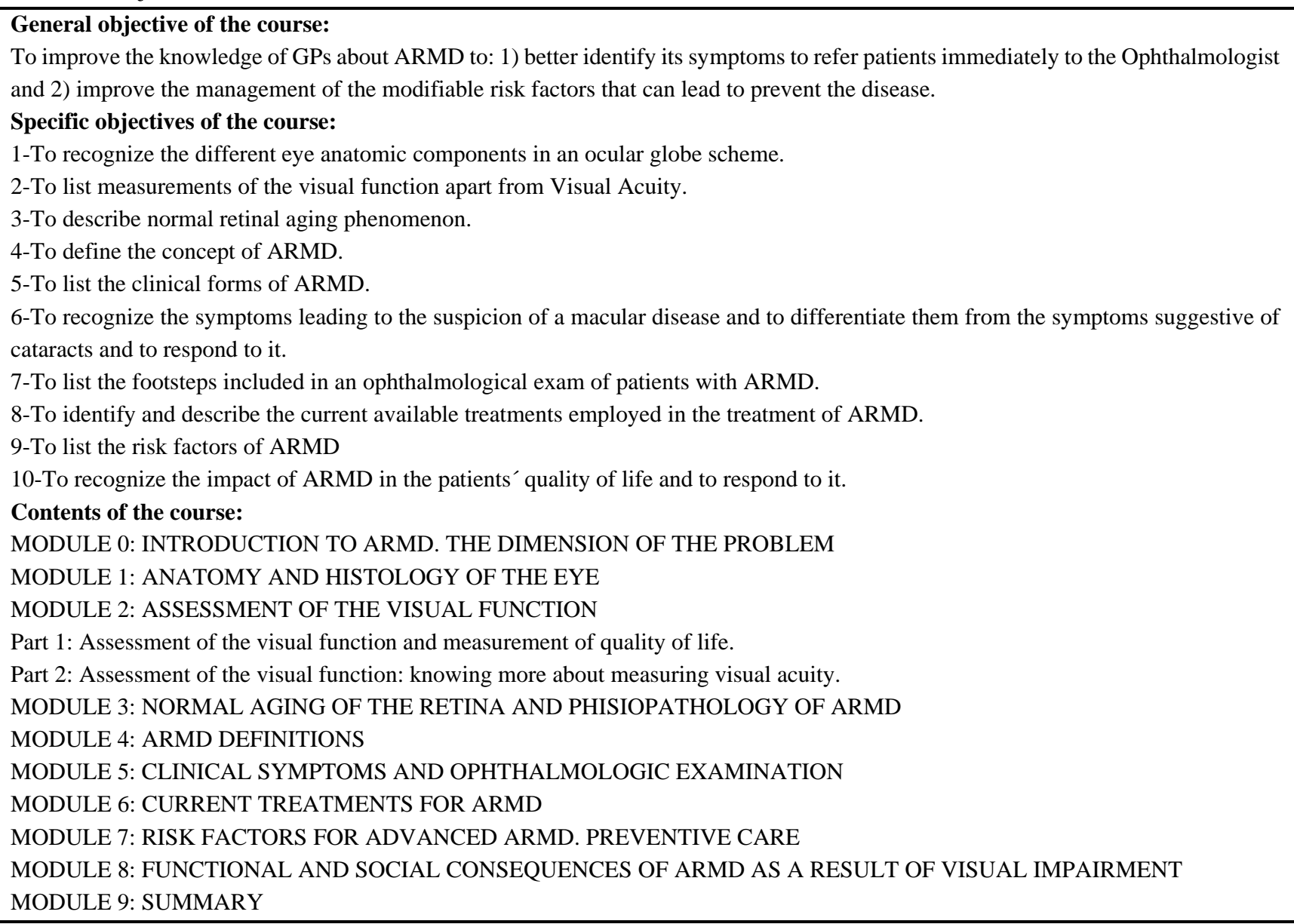


As evaluation method, students had to complete a small questionnaire with 4 multiple-choice questions for each module, which had to be answered correctly before gaining access to the contents of the next one. A final evaluation questionnaire was performed asking about all items explored in the postal questionnaire survey. Participants who committed major errors received an automatic fail in the exam. The Commission for Continuing Education of the Health Ministry of Spain gave 2.5 credits to the alumni completing this course that can be taken into account for their PC. The participants were also asked to complete a feedback questionnaire (Table 2).

Table 2. Satisfaction Questionnaire

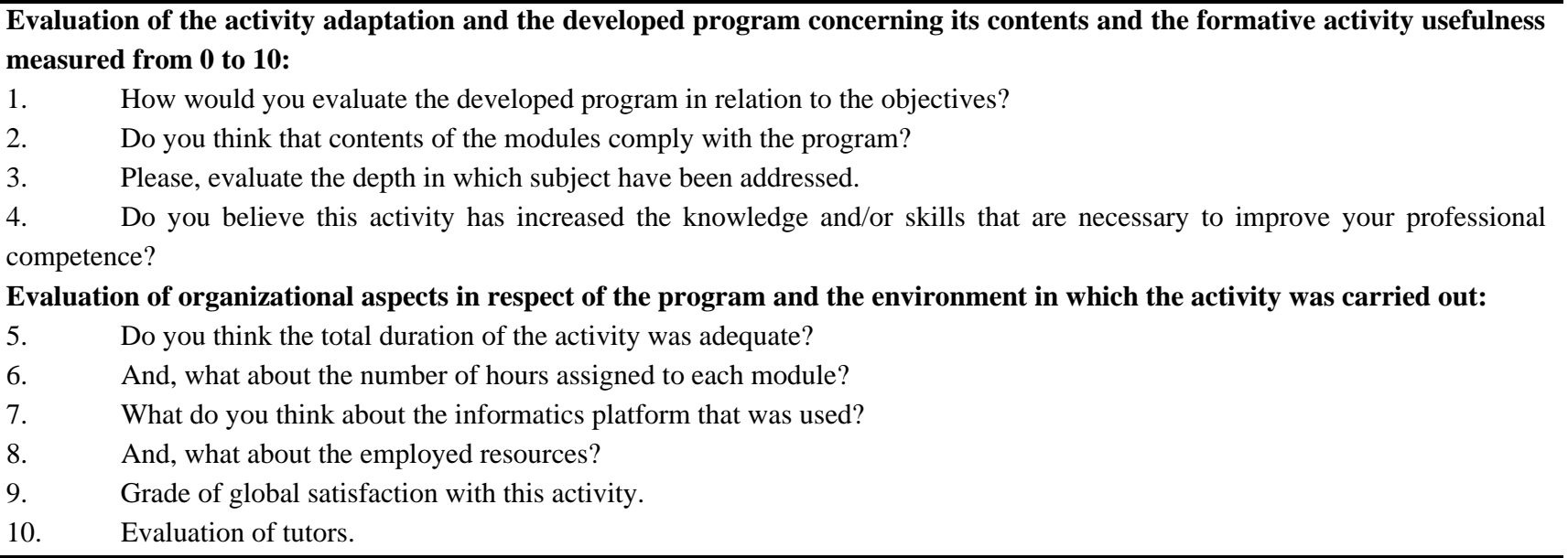

\subsection{Statistical analysis}

Quantitative results were expressed as means standard deviation, and categorical variables were described in percentages. A Chi-squared test was used to compare categorical variables. The Spearman Rho correlation coefficient was used to evaluate magnitude and direction of the association between two ordinal or interval variables. When one of the two variables was non-order categorical, Mann-Whitney $\mathrm{U}$ test was used to compare two groups and Kruskal-Wallis one-way analysis of variance by ranks was performed with three or more groups. To visualize the pattern of relationships between different response categories subsets, a multiple correspondence analysis was used. To determine whether there was a change after the course on the knowledge of the disease, the proportion of change was calculated as a summation of all the off-diagonal proportions in contingence tables. The McNemar test and 95\% confidence intervals (CIs) were used to assess the signification of this change. $P$-values $<0.05$ were considered statistically significant. The statistical analysis was performed with SPSS 15.0 for windows (SPSS Inc., Chicago, Illinois).

\section{Results}

\subsection{Postal questionnaire survey}

\subsubsection{Study population}

2365 physicians is the total population size of GPs in C\&L, 982 females (41.5\%) and 1383 males (58.4\%). The response rate was $30.6 \%(n=725)$. When we looked at the possible bias of non-response, we found no significant differences between responders and non-responders with respect to demographic characteristics, apart from gender, as the response rate was higher among females (33.7\% of the total female population versus $28.5 \%$ of the whole male population) being the Chi-square of Pearson=0.007. 
Looking only at the responders 368 were male (50.8\%) and 326 female (45\%), with a mean age of $50.9(\mathrm{SD}=5.2)$ years, range being from 29 to 65 years. The mean years of practice as GP was $23.7(\mathrm{SD}=6.04)$ and the mean number of patients 65 years or older of their quota was 338.7 ( $S D=217.5$ ) (approximately the $30 \%$ of the total of their patients). Doctors that had been practicing medicine for a longer time attended to a higher number of patients older than 65 (correlation coefficient Rho Spearman $=0.067$ ).

Table 3. Results on the general knowledge, risk factors, symptoms and treatment of ARMD before and after the course. Proportion of change in the knowledge of ARMD within the 68 physisians doing both, the survey and the course (left columns) are also presented. This was calculated as a summation of all the off-diagonal proportions, and McNemar $p$-value was then estimated.

\begin{tabular}{|c|c|c|c|c|}
\hline Knowledge on... & $\begin{array}{l}\text { Knowledge on the } \\
\text { survey }(n=725)\end{array}$ & $\begin{array}{l}\text { Knowledge after the } \\
\text { course }(n=164)\end{array}$ & $\begin{array}{l}\text { Proportion of change } \\
(n=68) \\
\%\end{array}$ & $\begin{array}{l}\text { McNemar } \\
p \text {-value }\end{array}$ \\
\hline Amsler grid & $\begin{array}{l}44 \% \mathrm{NA} / \mathrm{NK} \\
56 \% \mathrm{KA}\end{array}$ & $\begin{array}{l}4.3 \mathrm{NA} / \mathrm{NK} \\
95.7 \% \mathrm{KA}\end{array}$ & 34.3 & $<0.001$ \\
\hline Clinical forms & $\begin{array}{l}54.5 \mathrm{NA} / \mathrm{NK} \\
43.7 \% \text { correct }\end{array}$ & $\begin{array}{l}0.6 \% \mathrm{NA} / \mathrm{NK} \\
97 \% \text { correct }\end{array}$ & 47.1 & $<0.001$ \\
\hline Age of onset & $\begin{array}{l}18.3 \mathrm{NA} / \mathrm{NK} \\
45.5 \text { correct }\end{array}$ & $\begin{array}{l}2.4 \mathrm{NA} / \mathrm{NK} \\
93.3 \text { correct }\end{array}$ & 54.4 & $<0.001$ \\
\hline Bilaterality & $\begin{array}{l}26.9 \mathrm{NA} / \mathrm{NK} \\
49.9 \text { correct }\end{array}$ & $\begin{array}{l}\text { 2.4 NA/NK } \\
95.1 \text { correct }\end{array}$ & 64.7 & $<0.001$ \\
\hline High prevalence & $\begin{array}{l}31.3 \mathrm{NA} / \mathrm{NK} \\
58.7 \text { correct }\end{array}$ & $\begin{array}{l}1.2 \mathrm{NA} / \mathrm{NK} \\
96.3 \text { correct }\end{array}$ & 27.5 & $<0.001$ \\
\hline Familiar predisposition & $\begin{array}{l}53.4 \text { NA/NK } \\
40.4 \text { correct }\end{array}$ & $\begin{array}{l}1.2 \mathrm{NA} / \mathrm{NK} \\
97.6 \text { correct }\end{array}$ & 63.2 & $<0.001$ \\
\hline Tobacco & $\begin{array}{l}34.9 \mathrm{NA} / \mathrm{NK} \\
34.5 \text { correct }\end{array}$ & $\begin{array}{l}0 \mathrm{NA} / \mathrm{NK} \\
93.3 \text { correct }\end{array}$ & 67.6 & $<0.001$ \\
\hline Diet & $\begin{array}{l}34.2 \text { NA/NK } \\
12.6 \text { correct }\end{array}$ & $\begin{array}{l}0 \mathrm{NA} / \mathrm{NK} \\
75 \text { correct }\end{array}$ & 82.3 & $<0.001$ \\
\hline Vitamins intake & $\begin{array}{l}34.2 \mathrm{NA} / \mathrm{NK} \\
29.2 \text { correct }\end{array}$ & $\begin{array}{l}0 \mathrm{NA} / \mathrm{NK} \\
91.5 \text { correct }\end{array}$ & 75 & $<0.001$ \\
\hline Myopia (different disease) & $\begin{array}{l}34.9 \mathrm{NA} / \mathrm{NK} \\
40.7 \text { correct }\end{array}$ & $\begin{array}{l}0 \mathrm{NA} / \mathrm{NK} \\
89 \text { correct }\end{array}$ & 63.2 & $<0.001$ \\
\hline Sudden loss of vision & $\begin{array}{l}9.9 \mathrm{NA} / \mathrm{NK} \\
7.4 \text { correct }\end{array}$ & $\begin{array}{l}0 \mathrm{NA} / \mathrm{NK} \\
31.1 \text { correct }\end{array}$ & 48.5 & $<0.001$ \\
\hline Central scotoma & $\begin{array}{l}9.9 \mathrm{NA} / \mathrm{NK} \\
67.2 \text { correct }\end{array}$ & $\begin{array}{l}0 \mathrm{NA} / \mathrm{NK} \\
93.3 \text { correct }\end{array}$ & 39.7 & $<0.01$ \\
\hline Metamorphopsia & $\begin{array}{l}9.9 \mathrm{NA} / \mathrm{NK} \\
77.2 \text { correct }\end{array}$ & $\begin{array}{l}0 \mathrm{NA} / \mathrm{NK} \\
97 \text { correct }\end{array}$ & 19.1 & $>0.05$ \\
\hline Have ever suspected one case & $\begin{array}{l}0.6 \mathrm{NA} / \mathrm{NK} \\
51.9 \text { correct }\end{array}$ & $\begin{array}{l}0.6 \mathrm{NA} / \mathrm{NK} \\
50.6 \text { correct }\end{array}$ & 48.5 & $>0.05$ \\
\hline Laser & $\begin{array}{l}28.8 \mathrm{NA} / \mathrm{NK} \\
40.3 \text { correct }\end{array}$ & $\begin{array}{l}0 \mathrm{NA} / \mathrm{NK} \\
87.2\end{array}$ & 60.3 & $<0.001$ \\
\hline PDT & $\begin{array}{l}28.8 \mathrm{NA} / \mathrm{NK} \\
26.1 \text { correct }\end{array}$ & $\begin{array}{l}0 \mathrm{NA} / \mathrm{NK} \\
81.7\end{array}$ & 76.5 & $<0.001$ \\
\hline Anti-VEGF & $\begin{array}{l}28.8 \mathrm{NA} / \mathrm{NK} \\
30.1 \text { correct }\end{array}$ & $\begin{array}{l}0 \mathrm{NA} / \mathrm{NK} \\
96.3\end{array}$ & 61.2 & $<0.001$ \\
\hline
\end{tabular}

PDT = Photodynamic Therapy; Anti-VEGF = Anti-Vascular Endothelial Growth Factor drugs NA = does not answer; NK = does not know; correct = know the correct answer. Correct and not known responses are given in percentages; the rest until $100 \%$ would be the wrong answers. 


\subsubsection{Statistical results}

All the results are shown in Table 3 to 5. 20.66\% of GPs were not aware of the acronym ARMD. We also found that the more recent the GP's graduation, the higher the knowledge of ARMD acronyms and the use of the Amsler grid test $(p<0.021)$. Remarkably more than half of participants $(65.1 \%)$ indicated that they could identify patients at higher risk for the disease but just a few of the surveyed suspected smoking or diet as risk factors. The confusion of doctors thinking that myopia could be a risk factor of ARMD was surprising. We obtained fewer gaps in the group of questions about typical symptoms of ARMD, as they identify well central scotoma and metamorphopsia. They also could identify correctly that myodesopsias (81.1\%) and peripheral visual field loss (83.2\%) do not suggest macular disease.

More than $80 \%$ of participants believed that ARMD can be prevented but just a few would know how to do that: vitamins, diet or changes in habits like ceasing to smoke. Around one third of responders (33\%) did not know anything about prevention and very few knew about new treatments.

Table 4. Differences between the 11 sanitary areas from where students came, comparing people answering the previous questionnaire and people finishing the course $(p<0.001)$

\begin{tabular}{|c|c|c|c|c|c|c|c|c|}
\hline \multirow{3}{*}{$\begin{array}{l}\text { Sanitary geographic } \\
\text { area }\end{array}$} & \multicolumn{4}{|c|}{ GPs that answered the survey but did not do the course } & \multicolumn{4}{|c|}{ GPs that answered the survey and did the course } \\
\hline & \multirow{2}{*}{$\begin{array}{l}\mathbf{n} \\
198\end{array}$} & \multirow{2}{*}{$\begin{array}{l}\mathbf{\%} \\
95.6\end{array}$} & \multicolumn{2}{|c|}{$95 \% \mathrm{CI}$} & \multirow{2}{*}{$\begin{array}{l}\mathbf{n} \\
9\end{array}$} & \multirow{2}{*}{$\begin{array}{l}\mathbf{\%} \\
4.3\end{array}$} & \multicolumn{2}{|c|}{$95 \% \mathrm{CI}$} \\
\hline & & & 92.8 & 98.5 & & & 0.0 & 11.1 \\
\hline Burgos & 311 & 93.9 & 91.3 & 96.6 & 20 & 6.0 & 0,7 & 11.4 \\
\hline Leon (El Bierzo) & 114 & 96.6 & 93.3 & 99.9 & 4 & 3.4 & 0.0 & 12.4 \\
\hline Leon (capital) & 286 & 99.3 & 98.3 & 100 & 2 & 0.7 & 0.0 & 6.6 \\
\hline Palencia & 181 & 93.7 & 90.2 & 97.3 & 12 & 6.2 & 0.0 & 13.2 \\
\hline Salamanca & 324 & 97.6 & 95.9 & 99.2 & 8 & 2.4 & 0.0 & 7.8 \\
\hline Segovia & 161 & 89.9 & 85.3 & 94.6 & 18 & 10.0 & 2.9 & 17.1 \\
\hline Soria & 123 & 93.2 & 88.7 & 97.6 & 9 & 6.8 & 0.0 & 15.2 \\
\hline Valladolid (east) & 187 & 96.4 & 93.7 & 99.1 & 7 & 3.6 & 0.0 & 10.6 \\
\hline Valladolid (west) & 157 & 91.3 & 86.8 & 95.7 & 15 & 8.7 & 1.4 & 16.0 \\
\hline Zamora & 206 & 93.2 & 89.8 & 96.6 & 15 & 6.8 & 0.3 & 13.2 \\
\hline
\end{tabular}

$\mathrm{n}=$ number of subjects; $\mathrm{CI}=$ confidence intervals.

It was more likely to suspect a case of ARMD among GPs who usually see more patients a year affected of ARMD $(p<0.001)$. The number of patients over 65 years was higher among GPs who better suspect ARMD $(p<0.001)$. But, suspecting a case of ARMD depends on the knowledge of the disease. Multivariate statistical analysis showed that physicians who were more likely to suspect a case of ARMD had the following characteristics: they knew the acronym ARMD and the Amsler grid better, they had seen a higher number of patients with this disease a year and they had a better general knowledge about the disease. They also believed that smoking, iris colour and nutrition were risk factors, that prevention could be done with vitamin supplements, diet or changes in habits and they knew that potential treatments are photodynamic therapy and anti-VEGF drugs $(p<0.001)$.

Finally, 79.3\% of GPs sent patients complaining of metamorphopsia or central scotoma immediately to the Ophthalmologist. Sending the patient to the Ophthalmologist for routine examination instead of urgently was more frequent among those doctors who believe that prevention is not possible $(p<0.033)$. GPs who never suspected a case of ARMD tended not to indicate routine ophthalmological examinations. Also 97.3\% of the responders expressed their interest in receiving specific information about ARMD.

\subsection{On-line course and its effectiveness}

The total number of people enrolled in the course was 206, 187 finished it, and 164 sent the fulfilled evaluation questionnaire. In the group of non-apt people ( $n=42), 22$ only completed the first fifth of the course. The percentage of GPs 
answering that "they do not know about" almost disappears for most of the items after the course. The probability to suspect a typical case of ARMD after the course was much higher too.

Results on the change of knowledge within the group of 68 GPs performing both, the postal survey and the course are presented in Table 3. We found differences in the health areas from which people came, when comparing students doing the course with those answering the survey, being $p<0.001$ (Table 4).

\subsubsection{Study population}

The course was completed by 164 GPs, 67 male (40.9\%) and 97 female (59.1\%), with a mean age of 49.7 (SD=6.4) years (range 30-65). We found a higher number of female and younger doctors doing the course than the ones answering the survey. There were statistically significant differences regarding the years of practice, as people doing the course who did not respond to the survey had been practicing for a shorter number of years (Table 5).

Table 5. GPs finishing the course: data on physician's age, years of practice and number of patients older than 65 they attend

\begin{tabular}{|c|c|c|c|c|c|c|c|c|c|}
\hline & & \multirow{2}{*}{$\mathbf{n}$} & \multirow{2}{*}{ Mean } & \multirow{2}{*}{ S.D. } & \multirow{2}{*}{ Median } & \multirow{2}{*}{ Minimum } & \multirow{2}{*}{ Maximum } & \multicolumn{2}{|c|}{ CI 95\% for the average } \\
\hline & & & & & & & & Inferior & Superior \\
\hline \multirow{2}{*}{ Age } & NAS & 95 & 48,5 & 7,2 & 51 & 30 & 59 & 47,04 & 49,97 \\
\hline & AS & 68 & 51,4 & 4,7 & 52 & 40 & 65 & 50,25 & 52,54 \\
\hline \multirow{2}{*}{$\begin{array}{l}\text { Years of } \\
\text { practice as a } \\
\text { GP }\end{array}$} & NAS & 96 & 18,6 & 8,4 & 19 & 1 & 32 & 16,96 & 20,36 \\
\hline & AS & 68 & 23,9 & 6,2 & 24 & 10 & 39 & 22,41 & 25,42 \\
\hline \multirow{2}{*}{$\begin{array}{l}\mathrm{N}^{\circ} \text { of } \\
\text { patients }>65\end{array}$} & NAS & 88 & 263,6 & 213,7 & 200 & 0 & 1000 & 218,40 & 308,96 \\
\hline & AS & 66 & 244,6 & 127,9 & 200 & 50 & 608 & 213,21 & 276,12 \\
\hline
\end{tabular}

NAS = group of GPs doing the course that had not answered the previous survey; AS = group of GPs doing the course that did answer the previous survey; $\mathrm{n}$ = number of subjects; S.D. = standard deviation; $\mathrm{CI}=$ confidence intervals.

\subsubsection{Statistical results}

Remarkably $95.7 \%$ of students did get to learn how to use and interpret results of the Amsler grid test. The changes in knowledge were less obvious in the group of questions regarding typical symptoms of ARMD. After the course most GPs identify vitamins, diet or habits like ceasing to smoke as preventative measures and most physicians recognized intravitreal injections of anti VEGF and photodynamic therapy as possible treatments.

Figure 1. Satisfaction Questionnaire Results Average of the evaluation for any of the items presented in Table 2.

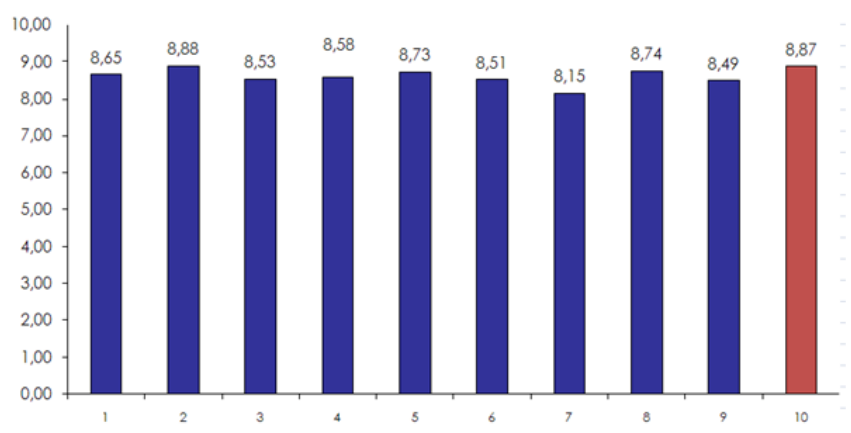

Statistical analysis showed that physicians who were more likely to suspect a case of ARMD had the following characteristics: they knew the acronym ARMD better and that prevention would be done with vitamin supplements and 
diet $(p<0.001)$. After the course most GPs would immediately send patients complaining of metamorphopsia or central scotoma to the Ophthalmologist. GPs who better suspect a case of ARMD tend to suggest urgent ophthalmological examinations to their patients $(p=0.02)$.

Feedback questionnaire showed nearly $90 \%$ satisfaction rate. Students suggested improving the course by increasing the clinical cases. Results are shown in Figure 1.

\section{Discussion}

In most communities, GPs are considered credible upstanding citizens whose opinions and recommendations are widely respected. Promoting eye health and the appropriate eye examinations are likely to be more effective if GPs are involved in it ${ }^{[15]}$. This is more relevant in regions like C\&L where the population is quite widespread in small villages, and its elderly population a big majority in the European Union. C\&L has a total of 2,546,078 inhabitants out of which 578,191 are older than 65 years old, and over $40 \%$ of them live in cities with fewer than 2,000 inhabitants ${ }^{[16]}$.

Despite what is stated above, the Macular Disease Society Questionnaire (which aimed to assess the experiences of people with macular disease within the British healthcare system) showed that many patients had had unsatisfactory experiences with their GP's. Most reasons for that dissatisfaction could be resolved if healthcare professionals had been better informed about macular diseases ${ }^{[17]}$. Our findings highlight that this is also happening in C\&L, which confirm our suspicions that GPs do not know enough about this disease either, and points out that it is a high-priority teaching topic.

In our survey we found so many gaps in the knowledge of this disease that we decided to prepare a complete and detailed course. Our results showed that a significant number of GPs did not even know the acronym ARMD, which is alarming, as no doctor can suspect or diagnose a disease that he/she has never heard about. It was also very important for us to teach them how to use the Amsler grid, as it is a low-cost and easy test to be used for the screening of macular pathology.

In addition, our findings suggest that older physicians tend to under diagnose this disease compared to the younger ones. The fact that those who had graduated more recently tended to better diagnose the disease shows that ARMD has become more relevant in medical studies in recent years.

But the most relevant finding in our study was that many GPs did not have enough information concerning most of the topics surveyed, even though they expressed interest in learning them. In a similar a study many physicians answering a web-based survey demonstrated favorable attitudes towards eye health and the role they should play in it. Approximately $60 \%$ indicated that they could identify patients at higher risk of developing eye diseases. However, only 52\% of the physicians indicated that they had adequate knowledge to advise their patients on vision health ${ }^{[18]}$.

A similar study carried out in diabetic retinopathy with a smaller number of doctors demonstrated that GPs would need detailed training if they had to be involved in early detection of eye diseases ${ }^{[19]}$. Another study on patient adherence to follow-up recommendations for eye diseases found that $43 \%$ out of 4918 consecutive patients had never consulted an Ophthalmologist in the last 3 years, although a quarter of them visited regularly their GPs when they had eye problems. Nevertheless, the latter did not know how to use diagnostic tools such as the Amsler grid or the swinging-flashlight test ${ }^{[20]}$. Those findings also point out that training GPs in eye diseases is something truly necessary.

The perceived usefulness or interest in following an online course include: access to learning, access to consistent content, links with assessment, convenience, cost saving, interactivity and time saving. ${ }^{[21]}$. In that sense, in our opinion, finding out the knowledge gaps of our population has helped to cover the specific needs of our learners increasing the possibilities of success in many of those components. 
The rate of participation was higher among women, as the general trend in all responses to surveys ${ }^{[22]}$. We also know that there are more females among younger doctors in C\&L. However, we believe the latter fact is not an explanation for the former, because it is important to remember that the mean age was around 50 years of age in both the group answering the survey and the group doing the course.

There are some other examples of online courses resulting in very high percentage of the overall award certificates compared to print course versions ${ }^{[23]}$, and our rate of success is high and similar to those ones. In addition, e-learning allowed us to offer the course to every GP notwithstanding working in rural areas and all around a vast region, which was also something we were aiming at.

The medical profession has long been recognized for its involvement in lifelong learning and CME is a means to facilitate it. However, if acquiring knowledge needs is documented and discussed, the learning process can be more successful than self-directed learning skills ${ }^{[24]}$. In our case, the GPs realizing they did not know about the disease were probably motivated to register for this course and to finish it, and that could have happened in the group of 68 GPs that had previously completed our survey.

From a physician-learner's perspective, CME has been and still is considered a mean to participate in short courses or conferences in order to fulfill a time-based credit system for their PC. From a physician-teacher's perspective, this will lead to increase the need for high quality CME activities in the future. This means greater rigor and involvement of physician-teachers. Future research in CME is needed, especially in those areas that require a rigorous process of retrieving, extracting, and synthesizing the data from CME activities ${ }^{[5]}$. We believe our study adds data to each of the above-mentioned points.

Finally, our study adds more evidence regarding the effectiveness of online CME programs to improve quality of care ${ }^{[25,26]}$. For this reason we are repeating our teaching activity as the next step to improve physician clinical practice in ARMD in our region and elsewhere ${ }^{[27]}$.

\section{Limitations of the present study}

There has not been a previous calculation of sample size as we had to analyze all the data we collected, this may reduce the validity the results Although we did not find differences between respondents and non-respondents in the survey, there may be a selection bias too. However we only compared the results achieved by the 68 GPs that both responded the survey and did the course. Another important limitation is that the study is restricted to a specific area of Spain. So there is no way to know for sure if the data may be extrapolated to other geographical areas.

\section{Conclusion}

The evidence from this study indicates that GPs lack the knowledge to adequately manage the patients with macular degeneration, for this reason a good learning process to improve ARMD detection and management is extremely necessary. In future courses, we will be updating the contents and increasing the clinical cases as suggested by pupils. We will also be investigating if the time between the beginning of the symptoms and the time of treatment is actually shortened after these courses.

\section{Conflict of interests}

Novartis-Spain funds the Novartis Chair of the University of Valladolid. Thus, the survey and the course were both funded by Novartis Ophthalmics-Spain.

Survey and education program were carried out also in agreement with the Health Department of the Castilla y Leon Regional Government. 


\section{References}

[1] Glossary of continuing medical education (CME) related organizations, committees, terms and credit programs. (2006). Chicago, IL, American Medical Education.

[2] Law 2/2007, de 7 de marzo, del Estatuto Jurídico del Personal Estatutario del Servicio de Salud de Castilla y León., Ley 2/2007, de 7 de marzo, del Estatuto Jurídico del Personal Estatutario del Servicio de Salud de Castilla y León., (2007).

[3] Dolcourt JL. Commitment to change: a strategy for promoting education effectiveness. J Contin Educ Health Prof. 2000; 20(3): 156-63. PMid:11232251 http://dx.doi.org/10.1002/chp.1340200304

[4] Harden RM. Trends and the future of postgraduate medical education. Emerg Med J. 2006; 23(10): 798-802. PMid:16988312 http://dx.doi.org/10.1136/emj.2005.033738

[5] Davis D, Bordage G, Moores LK, Bennett N, Marinopoulos SS, Mazmanian PE, Dorman T, McCrory D. The science of continuing medical education: terms, tools, and gaps: effectiveness of continuing medical education: American College of Chest Physicians Evidence-Based Educational Guidelines. Chest. 2009; 135(3 Suppl): 8S-16S. PMid:19265071 http://dx.doi.org/10.1378/chest.08-2513

[6] Macular Photocoagulation Study Group. Risk factors for choroidal neovascularization in the second eye of patients with juxtafoveal or subfoveal choroidal neovascularization secondary to age-related macular degeneration. Arch Ophthalmol. 1997; 115(6): 741-7. http://dx.doi.org/10.1001/archopht.1997.01100150743009

[7] Chopdar A, Chakravarthy U, Verma D. Age related macular degeneration. BMJ. 2003; 326(7387): 485-8. PMid:12609947 http://dx.doi.org/10.1136/bmj.326.7387.485

[8] Bird AC, Bressler NM, Bressler SB, et al. An international classification and grading system for age-related maculopathy and age-related macular degeneration. The International ARM Epidemiological Study Group. Surv Ophthalmol. 1995; 39(5): 367-74. http://dx.doi.org/10.1016/S0039-6257(05)80092-X

[9] Petrukhin K. New therapeutic targets in atrophic age-related macular degeneration. Expert Opin Ther Targets. 2007; 11(5): 625-39. PMid:17465722 http://dx.doi.org/10.1517/14728222.11.5.625

[10] Smith TC, Lee L. Age related macular degeneration - new developments in treatment. Aust Fam Physician. 2007; 36(5): 359-61. PMid:17492074

[11] Iu LP, Kwok AK. An update of treatment options for neovascular age-related macular degeneration. Hong Kong Med J. 2007; 13(6): 460-70. PMid:18057435

[12] Ruiz-Moreno JM, Coco RM, Garcia-Arumi J, Xu X, Zlateva G. Burden of illness of bilateral neovascular age-related macular degeneration in Spain. Curr Med Res Opin. 2008; 24(7): 2103-11. PMid:18547463 http://dx.doi.org/10.1185/03007990802214300

[13] Cruess AF, Zlateva G, Xu X, et al. Economic burden of bilateral neovascular age-related macular degeneration: multi-country observational study. Pharmacoeconomics. 2008; 26(1): 57-73. PMid:18088159 http://dx.doi.org/10.2165/00019053-200826010-00006

[14] Fletcher DC, Schuchard RA. Visual function in patients with choroidal neovascularization resulting from age-related macular degeneration: the importance of looking beyond visual acuity. Optom Vis Sci. 2006; 83(3): 178-89. PMid:16534460 http://dx.doi.org/10.1097/01.opx.0000204510.08026.7f

[15] National Eye Institute U.S. Department of Health and Human Services. 2005 Survey of Public Knowledge, Attitudes, and Practices Related to Eye Health and Disease [Internet]. Rockville, MD, USA: Government Printing Office; 2007. Available from: http://www.cescyl.es/pdf/informes/iniciativapropia/todoIP109.pdf

[16] Mitchell J, Bradley P, Anderson SJ, Ffytche T, Bradley C. Perceived quality of health care in macular disease: a survey of members of the Macular Disease Society. Br J Ophthalmol. 2002; 86(7): 777-81. PMid:12084749 http://dx.doi.org/10.1136/bjo.86.7.777

[17] Ammary-Risch N, Kwon HT, Scarbrough W, Higginbotham E, Heath-Watson S. Minority primary care physicians' knowledge, attitudes, and practices on eye health and preferred sources of information. J Natl Med Assoc. 2009; 101(12): 1247-53. PMid:20070013

[18] Khandekar R, Shah S, Al Lawatti J. Retinal examination of diabetic patients: knowledge, attitudes and practices of physicians in Oman. East Mediterr Health J. 2008; 14(4): 850-7. PMid:19166168

[19] Peltenburg M, Kiener M, Iseli HP, Trub P, Christen P, Hurni R, Aebi B, Steurer J, Gloor B. Preserving vision in the elderly: a survey to start a quality development program in general practice. Praxis (Bern 1994). 2004; 93(1-2): 9-14.

[20] Wong G, Greenhalgh T, Pawson R. Internet-based medical education: a realist review of what works, for whom and in what circumstances. BMC Med Educ. 2010; 10: 12. PMid:20122253 http://dx.doi.org/10.1186/1472-6920-10-12

[21] Tolonen H, Helakorpi S, Talala K, Helasoja V, Martelin T, Prattala R. 25-year trends and socio-demographic differences in response rates: Finnish adult health behaviour survey. Eur J Epidemiol. 2006; 21(6): 409-15. PMid:16804763 http://dx.doi.org/10.1007/s10654-006-9019-8 
[22] Brimmer DJ, McCleary KK, Lupton TA, Faryna KM, Reeves WC. Continuing medical education challenges in chronic fatigue syndrome. BMC Med Educ. 2009; 9: 70. PMid:19954535 http://dx.doi.org/10.1186/1472-6920-9-70

[23] Janke KK. Continuing professional development: don't miss the obvious. Am J Pharm Educ. 2010; 74(2): 31. PMid:20414444 http://dx.doi.org/10.5688/aj740231

[24] Weston CM, Sciamanna CN, Nash DB. Evaluating online continuing medical education seminars: evidence for improving clinical practices. Am J Med Qual. 2008; 23(6): 475-83. PMid:19001103 http://dx.doi.org/10.1177/1062860608325266

[25] Schwartzberg JG, Guttman R. Effect of training on physician attitudes and practices in home and community care of the elderly. Arch Fam Med. 1997; 6(5): 439-44. http://dx.doi.org/10.1001/archfami.6.5.439

[26] Coco RM, Sanabria MR, Fernandez I. E-learning strategies to improve GPs' ARMD knowledge. Medical Education. 2011; 46 (5): 517-8. PMid:22515775 http://dx.doi.org/10.1111/j.1365-2923.2012.04238.x 